\title{
Evidence for third-party mediation but not punishment in Mentawai justice
}

\author{
Manvir Singh $^{1 *}$, Zachary H. Garfield ${ }^{1}$ \\ ${ }^{1}$ Institute for Advanced Study in Toulouse, Université de Toulouse 1 Capitole, Toulouse, France \\ ${ }^{*}$ Corresponding author: manvir.singh@iast.fr
}

\begin{abstract}
Researchers argue that third parties help sustain human cooperation, yet how they contribute remains unclear, especially in small-scale, politically decentralized societies. Studying justice among Mentawai horticulturalists in Indonesia, we examined evidence for punishment and mediation by third parties. Across a sample of 444 transgressions we find no evidence of direct thirdparty punishment. Most victims and aggrieved parties demanded payment, and if a transgressor faced punishment, this was never imposed by third parties. We find little evidence of indirect sanctions by third parties. Nearly $20 \%$ of transgressions were followed by no payment, and as predicted by dyadic models of sanctions, payments were less likely when transgressions were among related individuals. Approximately $75 \%$ of all mediators called were third parties, especially shamans and elders, and mediators were called more as cooperation was threatened. Our findings suggest that, among the Mentawai, institutionalized penalties function more to restore dyadic cooperation than to enforce norms.
\end{abstract}

Social scientists have long argued that third parties help sustain human cooperation, yet how third parties contribute remains unclear. By some accounts, third parties sustain cooperation by enforcing cooperative norms. This view, tracing to the origins of sociology ${ }^{1}$, is supported by empirical and theoretical research, including evolutionary and economic models ${ }^{2-4}$, experiments conducted with children $^{5-8}$, experiments conducted in naturalistic settings and across societies ${ }^{8,9}$, and studies of large-scale cooperation among pastoralists ${ }^{10,11}$. Many reports of cooperation in small-scale settings, such as on pirate ships ${ }^{12}$ and in gold mines during the California gold rush ${ }^{13}$, further demonstrate that third-party enforcement maintains cooperation ${ }^{14}$.

This emphasis on third-party punishment has had important theoretical implications. Following Durkheim ${ }^{1}$, Boehm and Wrangham have argued that, in small-scale societies, social order is stabilized by the threat of coordinated punishment ${ }^{15-17}$. In fact, both maintain that many unique human traits, from the domestication syndrome to our moral emotions, evolved as communities collectively sanctioned deviants. Other researchers suggest that third-party punishment is critical for enabling profound levels of cooperation: When punishment becomes normative, people punish to avoid being punished themselves, potentially stabilizing any behavior, including contributions to large-scale cooperation ${ }^{10,18}$. By these accounts, human cooperation cannot be explained without considering third-party enforcement.

Despite the focus on third-party punishment, observations suggest it is less important among foragers, small-scale horticulturalists, and other societies in which individuals are connected through kinship and deep histories of reciprocity ${ }^{19-22}$. Compared to pirate ships, mining camps, and other communities of unrelated individuals, these societies exhibit conditions more similar to those of our ancestral past-including, for example, subsistence-based economies, local political authority, and stronger kinship ties-and thus serve as better models for understanding the evolution of human cooperation. Not only is third-party punishment infrequently observed in many such societies ${ }^{19-}$ ${ }^{22}$, but uninvolved parties often seem indifferent to whether wrongdoers suffer. In reviewing justice throughout aboriginal Australia, for instance, Berndt and Berndt noted that elders refrained from getting involved in many interpersonal conflicts ${ }^{23}$. When they did intervene, they tended to press "for settlement in non-violent terms" 24 , such as by organizing rituals of resolution. The preference for 
harmony over punishment makes sense. Recent research suggests that punishment, although justified as necessary for maintaining social order, often triggers retaliation and reflects competitive, rather than deterrent, motivations ${ }^{25}$. The reduced importance of third-party enforcement in many communities underscores the diversity of practices humans have developed to promote cooperation ${ }^{26,27}$.

If not enforcement, how else might third parties help sustain cooperation? Another view focuses on mediation, defined as an outside party providing counsel or direction in the resolution of a conflict. Mediation is important for at least two reasons: (1) Interacting partners may perceive a social interaction differently (i.e., there are perception errors), and (2) cooperators have conflicts of interest that bias reports of those perceptions ${ }^{28}$. As a result, cooperating partners end up in situations where they disagree about whether and to what extent a transgression has occurred, threatening to dissolve cooperation. Disputants may therefore call on third parties, especially those perceived as disinterested, to help clarify what occurred and how to resolve it. They may also call high-status individuals with reputations for fairness and special knowledge, as they may be both trusted and more effective as mediators.

Comparative studies suggest that mediation is common and often linked to leadership ${ }^{29}$. Analyzing ethnographic descriptions from a diverse sample of 59 mostly nonindustrial societies, Garfield et al. found that conflict resolution was the most frequent leadership function, appearing in $78 \%$ of societies ${ }^{30}$. A follow-up analysis revealed that "providing counsel and direction" was among the most common predictors of conflict resolution, with interpersonal skills and fairness following close behind ${ }^{31}$. Similarly, Glowacki and von Rueden found that leaders among both the Tsimane (Bolivia) and Nyangatom (Ethiopia) mediated conflict. In fact, conflict resolution appears to drive the institutionalization of leadership among the Nyangatom ${ }^{32}$.

Despite these findings, few studies have used naturalistic data of wrongdoing, punishment, and mediation to evaluate the roles of third parties in small-scale, politically decentralized societies. Mathew and Boyd provided evidence that punishment promotes participation in intergroup conflict among the Turkana of East Africa ${ }^{11}$, yet it is unclear whether their results apply to the majority of within-group transgressions. Wiessner, meanwhile, found that gossip and other verbal sanctions were common responses to norm violations among the Ju/'hoansi of northwestern Botswana, although their effectiveness appeared limited ${ }^{33}$. The most comprehensive recent contribution is Wiessner's study of conflict resolution among the Enga of Papua New Guinea, which documented diverse forms of third-party involvement, from compensation to help with restoration, with little evidence of punishment ${ }^{34}$. However, the generalizability of these findings to other ethnographic contexts remains unclear. For these reasons, we undertook a study of transgression and justice among the Mentawai people of Indonesia.

The Mentawai are an Austronesian people who inhabit the Mentawai Archipelago, approximately 150 kilometers off the west coast of Sumatra ${ }^{35}$. Our research focuses on Mentawai communities living in the interior of Siberut Island.

The Siberut Mentawai are rainforest horticulturalists whose main staple is the processed pith of sago palms. They also forage, raise pigs and chickens, and cultivate fruit trees and tubers. Although market foods are ubiquitous on the island, hunting and horticulture provide the bulk of people's diets ${ }^{36}$.

The Mentawai are organized into exogamous patrilineal clans called uma ${ }^{35,37}$. Clans are corporate groups. Fellow clan members share land and key resources on it, such as trees used to make canoes. Clans also exhibit some degree of corporate responsibility with clan members responsible for donating bride wealth or penalties for transgressions (tulou).

Traditionally, the Siberut Mentawai resided in longhouses (also known as uma) and small houses constructed nearby ${ }^{37}$. Following government settlement programs, most people have shifted to settlement villages (barasi), which host clinics, schools, mosques, and churches ${ }^{38,39}$. Clan members continue to live with each other in settlement villages, creating local clan-level districts, yet settlement villages still dramatically alter residence patterns by positioning different clans in close proximity. In the study area, many families maintain several residences, shifting between a small 
house or longhouse in the forest, where they raise pigs and conduct ceremonies, and a house in the settlement village.

Data were collected in several communities along the Rereiket River in the interior of Siberut. By "community", we mean a government village and the surrounding longhouses and forest settlements. Many interviews, as well as most participant-observation, occurred in a single community, hereafter known as "Community A". According to the regional administrative hierarchy, Community A constitutes a dusun, a sub-division of an administrative village (desa). Settlement and development programs in Community A have been recent. The dusun was established c. 2010 and the settlement houses constructed soon afterwards. The government-built elementary school (Sekolah Dasar, or SD) was introduced in 2016.

As of January 2020, Community A had three government officials: the Kepala Dusun (head of the sub-village), the Badan Permusyawaratan Dusun, or "BPD" (sub-village council representative), and the Perlindungan Masyarakat (community protection) officer, or Linmas (see ethnographic glossary in Table 1 for details). The three individuals filling these posts are drawn from the local community, often selected, it seems, for their literacy. The Kepala Dusun is responsible for demographic record-keeping and overseeing infrastructure projects. The BPD's duty is to represent the community's aspirations to the Kepala Dusun and to ensure the Kepala Dusun governs honestly and appropriately. Conflict resolution is overseen by the Kepala Dusun and Linmas.

Table 1. Ethnographic glossary

\begin{tabular}{|c|c|c|}
\hline Term $^{1}$ & English translation & Relevant details \\
\hline Dusun & Sub-village & $\begin{array}{l}\text { Dusun is an Indonesian term, referring to the administrative } \\
\text { subdivision of a desa, or village. The study community } \\
\text { ("Community A") constitutes a dusun. }\end{array}$ \\
\hline Ganti rugi & $\begin{array}{l}\text { Compensation for } \\
\text { money spent on school }\end{array}$ & $\begin{array}{l}\text { An Indonesian term meaning "compensation" (literally, } \\
\text { "substitute misfortune"), ganti rugi refers in Mentawai to when a } \\
\text { student must drop out of school and another family, deemed } \\
\text { responsible, must pay (typically when a female student } \\
\text { becomes pregnant). }\end{array}$ \\
\hline Keikei & Taboo & $\begin{array}{l}\text { People pay tulou for breaking taboos when the violation is said } \\
\text { to cause others harm. For instance, if a man visits another } \\
\text { man's wife while he is out hunting, it is said that the hunter may } \\
\text { return empty-handed or even injured, warranting tulou if either } \\
\text { happens. }\end{array}$ \\
\hline Kepala Dusun & $\begin{array}{l}\text { Government-appointed } \\
\text { sub-village head }\end{array}$ & $\begin{array}{l}\text { Translated as "head of the dusun", the Kepala Dusun is } \\
\text { responsible for demographic record-keeping (reporting deaths } \\
\text { and births) and overseeing infrastructure projects, including the } \\
\text { installation of cement roads and pipes for running water. }\end{array}$ \\
\hline Kerei/sikerei & Shaman & $\begin{array}{l}\text { Kerei is used to describe both a male shaman and his wife, } \\
\text { each of whom must observe permanent dietary taboos that } \\
\text { mark their special status. Nevertheless, male shamans, and } \\
\text { not their wives, are typically the only ones called to provide } \\
\text { shamanic services. }\end{array}$ \\
\hline Kirekat & $\begin{array}{l}\text { Memorialized durian } \\
\text { tree }\end{array}$ & $\begin{array}{l}\text { Following a person's death, their likeness (height and outlines } \\
\text { of hand and feet) is carved on a durian tree, memorializing } \\
\text { them. }\end{array}$ \\
\hline Linmas & $\begin{array}{l}\text { Community protection } \\
\text { officer }\end{array}$ & $\begin{array}{l}\text { An Indonesian term short for "Perlindungan Masyarakat" } \\
\text { ("community protection"), Linmas officers are officially } \\
\text { responsible for maintaining order and preparing for disasters. } \\
\text { In Mentawai, they are often also known as Hansip, a now- } \\
\text { defunct administrative role. }\end{array}$ \\
\hline Lulut & Price of a human life & $\begin{array}{l}\text { The lulut is paid to the family of someone killed through } \\
\text { homicide or sorcery. }\end{array}$ \\
\hline
\end{tabular}




\begin{tabular}{|c|c|c|}
\hline Pasuili/patalaga & Mediator & $\begin{array}{l}\text { Mediators are called not only during conflicts but also when } \\
\text { negotiating bride-prices. }\end{array}$ \\
\hline Sikebbukat & (Senior) elder & $\begin{array}{l}\text { The oldest members of a clan, the sikebbukat are endowed } \\
\text { with special decision-making privileges, such as selling clan- } \\
\text { owned land. }\end{array}$ \\
\hline Tulou & $\begin{array}{l}\text { Penalty and } \\
\text { compensation payment }\end{array}$ & $\begin{array}{l}\text { Often translated as "fine", tulou is paid from an offender to a } \\
\text { victim and is often said to comprise a compensatory portion } \\
\text { (silinia) and a punitive portion (tulounia). The word tulou is the } \\
\text { root of both tulougi (to demand a tulou) and patulougat (the act } \\
\text { or process of tulou). }\end{array}$ \\
\hline Uma & $\begin{array}{l}\text { Patrilineal } \\
\text { clan/communal } \\
\text { longhouse }\end{array}$ & $\begin{array}{l}\text { Clans are also referred to using the Indonesian word for ethnic } \\
\text { group, suku. }\end{array}$ \\
\hline
\end{tabular}

${ }^{1}$ Mentawai or Indonesian terms are italicized.

Aside from governmental officials, there are at least three classes of individuals who serve as leaders in Mentawai:

- Sikerei, or shamans, act as conduits between the visible and invisible worlds ${ }^{40,41}$. Believed to see people's souls and the spirits that cause illness, sikerei apparently commune with these spirits in healing ceremonies (pabetei) ${ }^{41}$. They also organize some religious activities, such as inviting ancestors before a ceremony.

- Ritual leaders organize other household and community ceremonies. They coordinate activities, perform ritual actions on behalf of others, and sacrifice animals. During ritual periods, they become proto-sikerei, observing the taboos that shamans must always observe. Historically, it appears that each uma (longhouse/patrilineal clan) may have had a more formal ritual leader, known as the rimata ${ }^{35,37,42,43}$. In the studied communities, however, ritual leadership is much more flexible.

- Sikebbukat are elders and the oldest members of clans. People defer to them for their expertise. Although the sikebbukat seem endowed with certain decision-making privileges (e.g., selling clan land), decisions appear to be made collectively with the sikebbukat representing or consolidating group opinion.

Transgressions in Siberut are commonly followed by tulou, a payment of resources from the aggressor to the victim (the process of paying tulou is known as patulougat). The Mentawai conceptualize tulou as more punitive than simple compensation, often describing a tulou payment as including a replacement to make up for lost or stolen resources (silinia) and an additional penalty (tulounia). As a result, people are careful when using the term tulou. For instance, M.S. observed a discussion in which a man confronted his great-uncle after concluding that the great-uncle stole the man's pig (Box 1). The man was careful to tell his great-uncle he sought a replacement, not a tulou. In fact, many anthropologists who have worked with the Mentawai-including Tulius, who is himself Mentawai-define tulou as "fine" or "punishment" $35,37,38,44-47$.

\section{Box 1. Case: A man steals his great-nephew's pig and sells it to him (TULO-391)}

All individual and clan names here are pseudonyms; the ID (TULO-XXX) refers to the case ID in the dataset available on the OSF page.

Alei Manai paid his great-uncle (father's father's brother) Teu Rara to find him a pig. Teu Rara delivered it, but after killing and sharing the pig, Alei Manai started to suspect that Teu Rara stole his pig from their clan's pig area. In other words, it looked like Teu Rara sold Alei Manai his own pig. Alei Manai talked about his suspicions publicly, enough so that they probably reached Teu Rara. Meanwhile, someone else in Alei Manai's clan suspected Teu Rara of stealing a different pig.

One day, Teu Rara arrived at Alei Manai's house. Alei Manai offered Teu Rara food, but he refused. Teu Rara began to talk about pigs. Three unrelated men, including the government-appointed Linmas, arrived to socialize. They stayed and observed.

Apologizing for any rudeness, Alei Manai said that Teu Rara took his pig. He said that he simply wanted a replacement. He did not want tulou from Teu Rara. That would be a ruder, more involved affair. The Linmas 
agreed and emphasized that Alei Manai and his great-uncle were the only two members of their clan in this community. They relied on each other.

Alei Manai spelled out two alternatives. "You say that it's your pig. It's done-[for] me." But if Teu Rara admitted to taking Alei Manai's pig, then, "really, l'm just looking for a single replacement," said Alei Manai. "The end." and left.

Alei Manai said he wasn't interested in the other accusations. Meanwhile, the Linmas excused himself

Teu Rara offered to "cut the sasa", a ritual that punishes liars with death. He would take the skull of the pig he gave Alei Manai, as well as the skull of the other pig he purportedly stole. He would deny stealing the pigs and cut sasa, a kind of rattan. Perhaps he mistook Alei Manai's pig for his own and did take it by accident. He would die, of course, but, in his words, "that's not really a problem."

Yet, he went on, if they cut the sasa and he survived, then Alei Manai shouldn't reach out to him. And if they cut the sasa and Alei Manai survived, then Teu Rara wouldn't reach out to him either.

Alei Manai conceded. He said, "If this pig belongs to you, it's done. There isn't anything else to say-to the dusun [sub-village government], to whomever-nothing. I don't like that. We're distant. We're uncomfortable. We're shy. We're embarrassed."

Again, he emphasized that he didn't care about the other accusations. "This pig, this one, your pig-it's done." In this community, he said, it was just the two of them from their clan. "You're not someone else [someone more socially distant]. I'm not someone else. It's just us here. If anyone does something to you, there's me. If anyone does something to me, there's you. [So], this pig. This isn't my uncle's pig [referring to the other person who had accused Teu Rara]. It's done."

According to our data, tulou payments followed a variety of transgressions, including (presumably) committing malevolent magic, committing adultery, destroying special durian trees, impregnating an unmarried girl, inducing bad luck by breaking taboos (such as by having sex with a married shaman or approaching a man's house while his wife was home and he was away hunting), saying the name of a person's dead family members, spreading malicious rumors, and, most frequently, stealing or damaging property, including pigs, chickens, bananas, and sago trees (see Table 1 for details). The most common components of tulou are pigs, sago trees, durian trees, coconut trees, cooking woks, and chickens, although recorded cases also include payments in money, mosquito nets, machetes, gardens of taro, canoe motors, and other resources. Although food-sharing constitutes a (if not the) major cooperative domain in Mentawai society ${ }^{39,41,46,48}$, violations of food-sharing norms are almost never followed by tulou.

Tulou payments vary in their composition, even for transgressions that appear the same. Nevertheless, simple principles guide the payment of tulou, as captured in the common adage sabbek silinia, sabbek tulounia. This phrase, which means "one [is] its replacement, one [is] its tulou" (loosely: one part compensatory, one part penalty), dictates that the value of a payment should be equivalent to twice the value of the destroyed or stolen property.

Other factors that influence the magnitude of a payment include whether the transgression was hidden (higher payment), whether the transgression was intentional (higher), whether the transgressor was a recidivist (higher), and whether an offender was an animal or a child, such as when one's pig eats another's chicken (lower). As the case in Box 2 demonstrates, intentionality is complicated. Someone may accidentally kill a pig while hunting. Yet unless circumstances are exceptional-the owner did not mark their pig, for instance-accidental killings of livestock are treated as intentional offenses.

\footnotetext{
Box 2. Case: A deer trap kills a cow (TULO-409)

All individual and clan names here are pseudonyms; the ID (TULO-XXX) refers to the case ID in the dataset available on the OSF page.

Opa Kerei of the clan Sabilou set a deer trap, accidentally killing a large cow owned by Aman Raman (clan Tasiripora). Opa Kerei immediately told Aman Raman, who decided to split the cow and share the meat. Aman Raman said they would negotiate the tulou payment with members of both clans at the house of the Kepala Dusun (government-appointed village head).

The community buzzed with anticipation. Cows are rare, prized possessions. This animal-later determined to be worth about 10 large, female pigs-was the only one in the study area and a gift from a foreigner. People talked about how the decision to split the cow was a noble one, one that would mean a lighter payment for Opa Kerei and his clanmates. Still, though, it would be severe. One man said the value would exceed
} 
a lulut (price of a human life). Another told M.S. that, if he were in the situation, he would hang himself where the cow died. A third said that no one alive has enough babui (large, male pigs) to pay. Over and over, M.S. walked into houses to conduct interviews for other projects and found people talking about the cow.

The discussion took place two days after the cow died, at night (Figure 1). Thirty or so people were in attendance, many from third-party clans. The dispute was mediated by two government officials: the Kepala Dusun and the Linmas. Both were members of local clans, although neither was a member of a disputing clan.

The officials started by establishing the rules of the conversation: The disputants should aim to resolve the conflict that evening and should communicate respectfully, one-by-one, and without rude language or yelling. The Linmas used the analogy of a talking drum (tuddukat). The talking drum cannot communicate if you only hit one part of it. Similarly, no single person should dominate the conversation.

During the first thirty minutes, the disputants established details necessary for determining an appropriate tulou. Opa Kerei admitted that it was his fault but pointed out that it was unintentional and that he did not hide the transgression. Aman Raman replied that it would've been impossible to hide a dead cow and that Aman Raman's son had warned Opa Kerei not to put a deer trap there. Aman Raman reviewed the values of previous tulou payments for killed cows. The Kepala Dusun summarized the disputants' points.

After half an hour, Aman Raman laid out his demands-a debilitatingly expensive payment that would include, among other components, two cows, a chainsaw, several pigs, and large cooking woks. Following some discussion, the Linmas suggested that Opa Kerei's clan start with the cheapest items and move towards the most expensive. Opa Kerei and his clanmates agreed to pay 3 pigs, a garden of sago, 2 large cooking woks, a garden of durian, 3 more durian trees, a coconut tree, and a taro field (or replacements). They refused to hand over a chainsaw and had yet to talk about cows.

An hour into the discussion, Teu Rigi, an elder shaman of Opa Kerei's clan who had until then stayed quiet, remarked at the obscenity of the demands ("this isn't tulou for half a cow"). Aman Raman and his sons interrupted him, but Teu Rigi continued speaking. Aman Raman's youngest son said that it was never their intention to take these resources, but a cow had been killed. As the men spoke over each other, Aman Raman's oldest son clamored, "Let's not dwell on the feud"-a reference, it seems, to past sorcery accusations. His younger brother said that, if he fell ill, his uncle (Teu Rigi) was to blame. Teu Rigi said the same in response. The men started yelling, speaking faster and in higher-pitched voices, while observers, especially women, tried to relax the situation. "It's finished," they said, and, "let's slow it down." Within a minute, Aman Raman's oldest son emphasized moving beyond the past: "New_-indeed new." Teu Rigi left and the conversation became convivial again.

For the next twenty minutes, Opa Kerei's clanmates located the particular trees and gardens to be transferred to Aman Raman. Once that was resolved, the government officials suggested removing the chainsaw and one of the two cows. Speaking for the victims, Aman Raman's oldest son agreed. He said that he, his brothers, and his children had long lives ahead of them. He was looking for good relationships. His father may yell at him, but he preferred to find a solution that made everyone happy.

After a short break, the disputants discussed the indebted cow. No one in Opa Kerei's clan-let alone in this village or the next one over-had a cow. They finally decided that the offenders would slowly amass money, however long it took, and buy a large, female cow from a mosque upriver.

Two and a half hours in, the Kepala Dusun announced the conflict's resolution. He thanked both of the parties and emphasized the importance of resolving disputes in-person, in a single sitting, through the government. Specific trees and gardens were now transferred to Aman Raman and his sons. Cooking woks and pigs were to be delivered in the next couple of days. Opa Kerei owed Aman Raman one cow. After the Kepala Dusun concluded the dispute, Opa Kerei's older cousin lectured his younger cousins, communicated just how severe the tulou was ("if you all make another mistake, they will slash us"), and clarified that, in his eyes, there was no feud.

Typically, a transgressor and closely related clan-mates pay tulou to a victim and their clanmates. In fact, many participants described tulou payments as occurring between clans rather than between individuals. Still, the structure of the coalitions demanding and paying tulou varies. At one extreme, close family members sometimes demand tulou from each other. When a father groped his son's wife, for instance, the son and his wife demanded tulou from the father. At the other extreme, clans may come together to demand that transgressors pay, particularly when shared resources are damaged or stolen. For example, at least five clans who shared a stretch of forest collectively demanded tulou from people living upriver who harvested rattan on their land. Finally, many sublineages within a clan or related clans may demand tulou from fellow clan members who overharvest shared resources.

The tulou system predates colonial and state presence in Mentawai. Tulius collected ancestral stories chronicling migration and land ownership in Mentawai; many featured the payment of tulou and, occasionally, conflict and fission following people's refusal to pay ${ }^{35}$. One storyteller 
described how his ancestors nearly ten generations earlier had demanded payment after a neighboring clan killed and consumed a pig; others recounted how land owned by their families came from earlier tulou payments.

In the study communities, individuals demand and negotiate tulou in several ways. Injured parties sometimes visit transgressors and negotiate without mediation. Other times, the injured party hires a mediator, known as pasuili or patalaga (from talaga, or "middle"), to visit the offender and negotiate payment. The mediator travels between the parties until a decision is made and tulou is paid (or not). The injured party and the offender may also meet in a common place with the mediator structuring the discussion. Following payment, victims pay mediators for their services. In three cases, for instance, the mediator was paid a durian tree, while in a fourth, they received a coconut tree.

With the introduction of government offices, some injured parties report infractions to the government-appointed Kepala Dusun and Linmas, who invite disputing parties to a meeting place and mediate (Figure 1). Although they represent the Indonesian government, governmental mediators function similarly to local mediators. As illustrated in Box 2, they aim to resolve conflicts quickly and amicably; they make recommendations but seem to lack enforcement power; and although they might provide commentary or suggestions in cases that are not brought to them, they are not responsible for staying to resolve them. In very rare circumstances, cases unresolved at the dusun level are brought to higher governmental officials-first to the desa (village), then to the kecamatan (district).

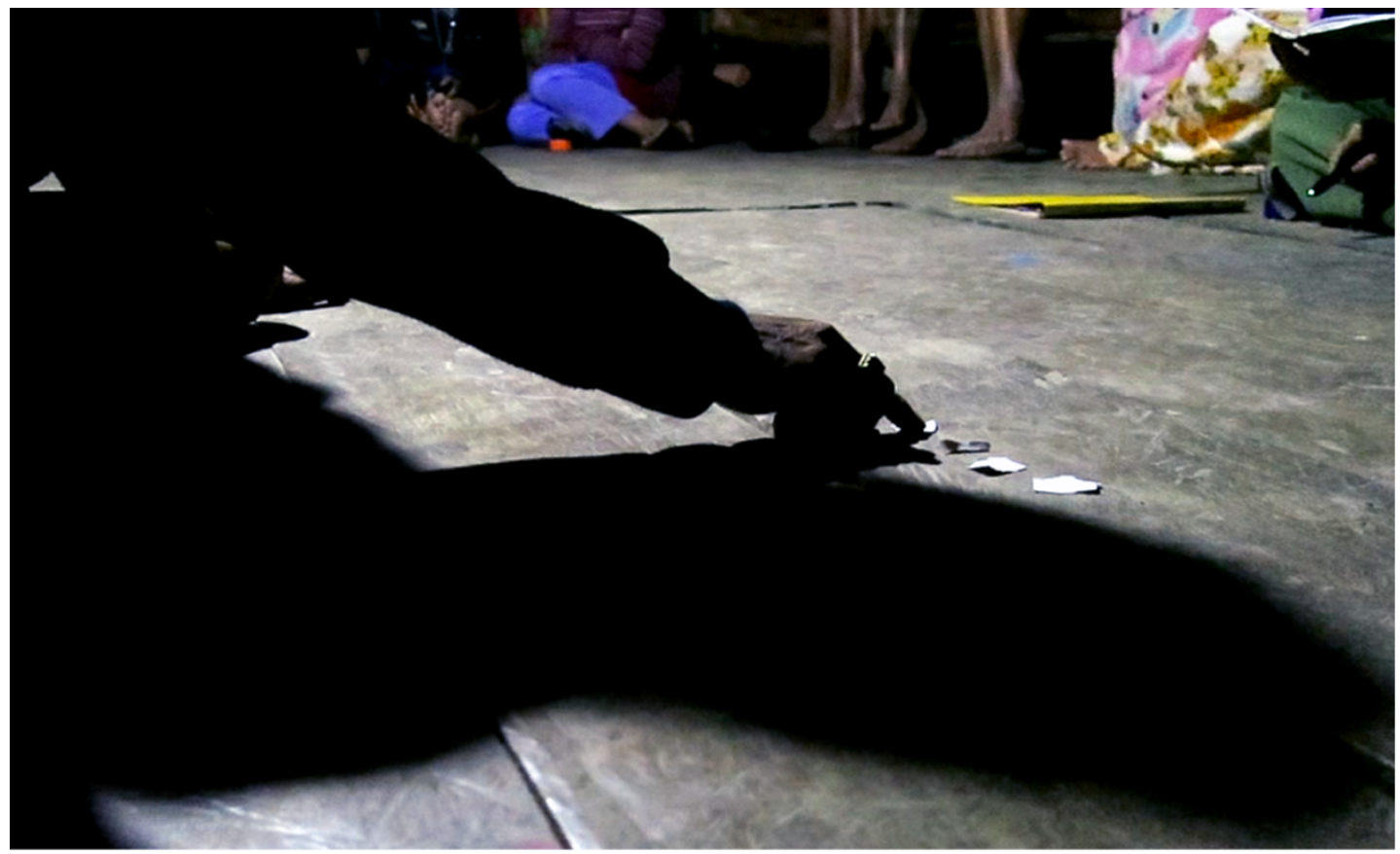

Figure 1: A victim lists his demands. This photograph was taken during the case described in Box 2 . The white pieces of paper represent components of the tulou payment, such as pigs, durian trees, coconut trees, gardens of sago, and large cooking woks. The folder in the top right corner belongs to the government-appointed officials, who acted as mediators for this case. Source: Manvir Singh.

Historically, Dutch and then Indonesian administrators strove to reform the tulou system, either by standardizing payments or by replacing tulou with other punishments ${ }^{49,50}$. As with other acculturation programs, these efforts were less successful in Siberut's interior than elsewhere in the Mentawai archipelago and were relaxed in the late $1980 \mathrm{~s}$ and early $1990 \mathrm{~s}^{39,50}$. Although government officials like the Kepala Dusun and Linmas are today involved in disputes, they are drawn from the local community and do not apparently endorse Indonesian laws or standards of punishment over Mentawai customs, instead relying on principles such as sabbek silinia, sabbek tulounia to 
determine whether a transgression occurred and how it should be dealt with. Nevertheless, it is possible that disputants adjust their demands to avoid interference from officials outside the local community.

To understand wrongdoing and justice in Mentawai, M.S. conducted 199 interviews with 95 participants in 2017. All interviews were conducted in the Rereiket dialect of the Mentawai language. Participants were asked to share details about transgressions they were aware of, starting with tulou payments they had paid or demanded. M.S. also noted and observed tulou payments and other transgressions during 12 months of fieldwork. In total, details about 444 cases were collected. Because much of our data comprise retrospective reports, we used a set of exclusion criteria to restrict the sample, leaving 302 cases. For more details about data collection, cleaning, exclusion, and analysis, see the Methods section.

\section{Results}

For any given conflict, we distinguish among three parties:

- Second-parties (or victims) are those directly harmed by a transgression, such as the person from whom a pig is stolen.

- Aggrieved parties are close patrilineal relatives, first-degree relatives (e.g., children, parents), or spouses of second-party individuals.

- Third parties are all remaining individuals, excluding close patrilineal relatives, first-degree relatives, and spouses of transgressors.

We distinguish between aggrieved and third parties because the corporate structure of clans leads to interdependence among close patrilineal relatives and an overlapping of interests, especially in the context of transgression. Patrilineal clans involve some degree of corporate responsibility and related clan members are, to some extent, substitutable: Historically, and more rarely today, a person might be attacked as retribution for a fellow clan member's transgression. Fellow clan members, especially closely related ones, typically receive part of any tulou that is paid, and they are usually responsible for contributing to a tulou payment if a clan member commits a transgression.

\section{No evidence of third-party punishment}

We consider third-party punishment on a continuum, from least costly (demanding tulou on a victim's behalf) to most costly (attacking a transgressor or seizing resources).

Of 302 cases for which data were reliable, none provided an indication that third parties expend costs to punish transgressors. Of the 249 cases in which tulou was paid, we documented no case in which a party other than the victim, their close patrilineal relatives, or the victim's spouse demanded that a transgressor pay. In 4 instances, a transgressor refused to pay and was in turn punished (resources were seized from them; Supplementary Table 1). Such punishment was always imposed by the victim or their immediate family and never by third parties.

Having found no evidence that third parties directly punish, we next investigated indirect sanctions by third parties. Theoretical work suggests that punishment itself may become a normative act maintained by second-order sanctions ${ }^{4,51}$. In line with these models, Mathew found that Turkana adults disapproved of a hypothetical raider who did not punish a coward from his age group ${ }^{10}$. In Mentawai, such hypothetical second-order sanctions might manifest as third parties avoiding either transgressors who fail to pay or second parties who fail to demand or enforce tulou payments.

Several lines of evidence suggest that indirect, second-order sanctions do not have a substantial impact in Mentawai justice. First, we did not find instances of such sanctions across the 302 cases, although we acknowledge they are harder to document. Second, as Figure 2 shows, the distribution of tulou prices was bimodal, especially among less severe transgressions. Of 298 transgressions for which relevant data are available, 51 (17.1\%) were followed by no tulou payment. This does not necessarily mean that indirect sanctions by third parties do not motivate individuals to pay or enforce tulou—but if they do, they apparently fail often. 


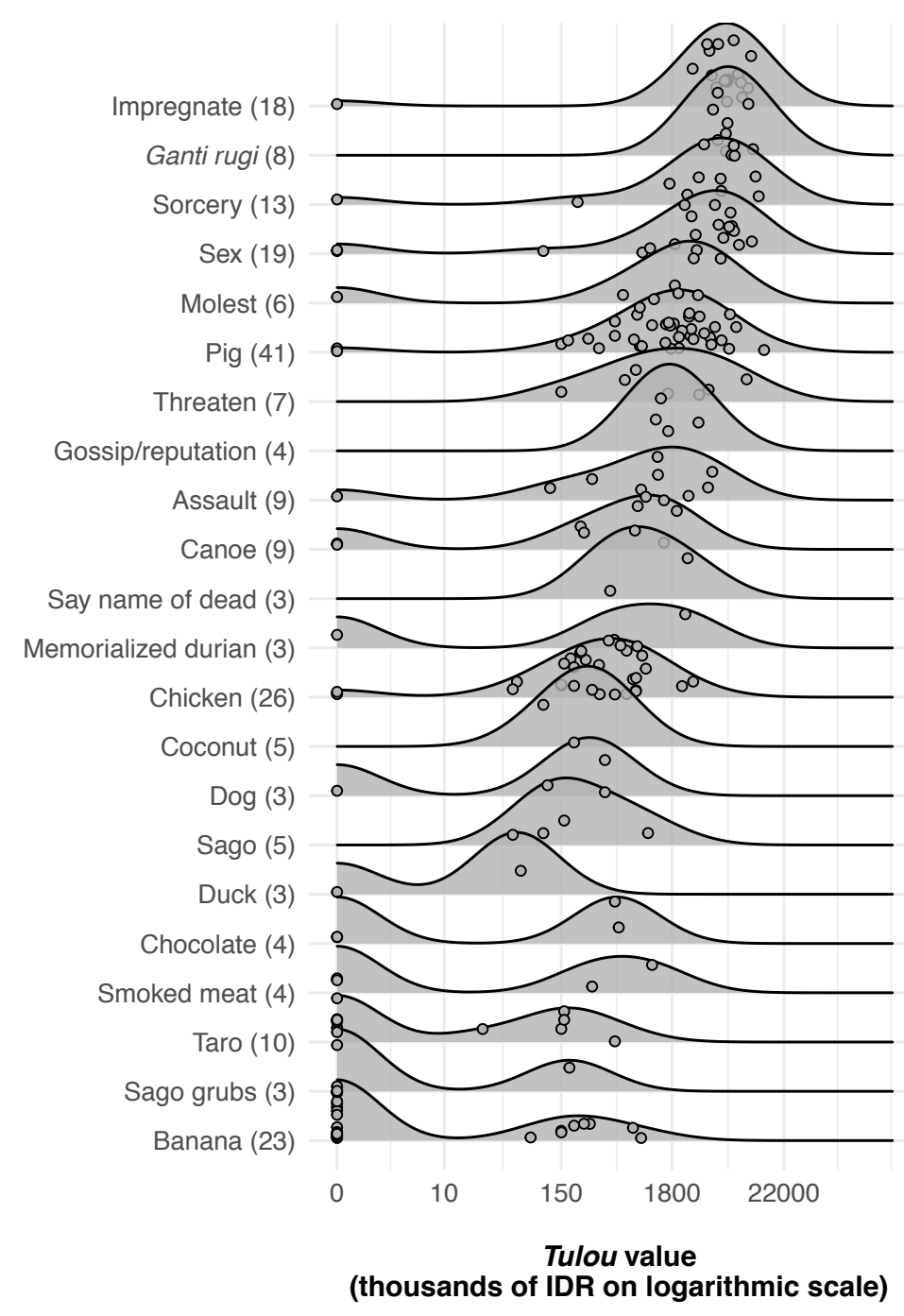

Figure 2: The distributions of tulou payments for different categories of transgression. Payment values in Indonesian rupiah appear on the $\mathrm{x}$-axis and are plotted on a logarithmic scale. Categories of transgression appear on the $y$-axis and are ordered by the median value of payments. The numbers in parentheses next to each category name indicate the number of cases in that category; only categories with 3 or more cases appear. Named resources such as 'Pig', 'Chicken', and 'Bananas' refer to resources that have been stolen or destroyed. 'Molest' refers to kissing, groping, and sexual advances. For further details, see the ethnographic glossary in Table 1.

Third, we investigated whether dyadic concerns, rather than indirect sanctions, explain the presence or absence of paying penalties. According to dyadic accounts, imposing costs on transgressors serves to restore cooperation, either because it reduces fitness differences or because it deters aggressors from future exploitation ${ }^{52,53}$. Such accounts predict that such cost imposition will be more likely when cooperation is under greater threat. We tested this prediction by comparing the likelihoods of tulou payments when transgressions occurred among clan members and when they occurred among non-clan members. Because they are supported by links of kinship and reciprocity, cooperative relationships within clans are more robust to shocks than cooperative relationships between clans. According to cooperation-restoration hypotheses, then, between-clan transgressions should more often result in tulou payments.

We used Bayesian logistic regression to model the likelihood of tulou as a function of whether a transgression occurred within or between clans (model 1; see Methods). We found that tulou payments are less likely for within-clan transgressions $(n=53)$ than for between-clan 
transgressions ( $n=224$; analyses exclude cases for which the category of wrongdoing or clan status of disputants is unknown or ambiguous). The odds that a tulou payment occurs following a transgression within a clan is about 0.563 -times the odds that a payment occurs after a betweenclan transgression (log odds: mean $=-0.574 ; 93.9 \%$ of posterior distribution $<0$ ). This pattern holds when adjusting for the severity of transgressions (model 2; log odds: mean $=-0.613 ; 94 \%$ of posterior distribution <0; Figure 3).

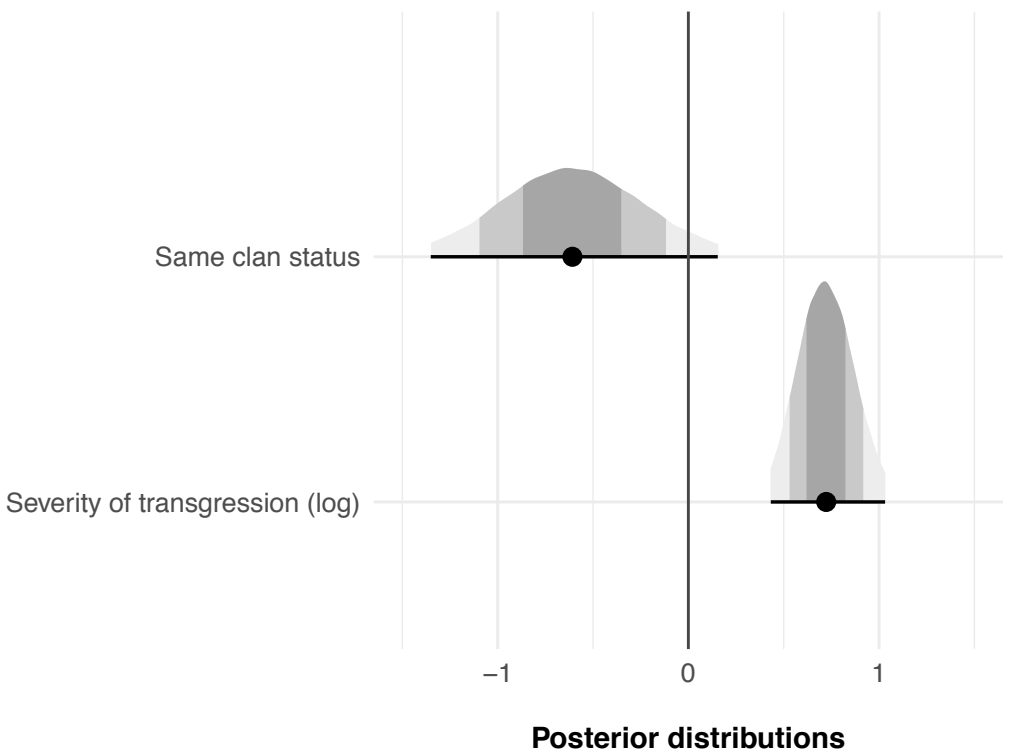

Figure 3: Predictors of a tulou payment occurring. The figure shows the estimated log odds (x-axis) for predicting whether a tulou payment occurs (model 2) ( $n=271$ cases). 'Same clan status' is a binary variable capturing whether disputants are in the same clan (1) or different clans (0). Points and error bars are posterior means with $95 \%$ credible intervals. The shaded areas and distributions respectively represent $50 \%, 80 \%$, and $95 \%$ of the posterior distributions.

These quantitative results were supported by participants' anecdotal reports. We asked 36 participants why the tulou payments they reported were especially cheap or expensive; Supplementary Figure 1 displays responses. The most common reason mentioned $(25 \%$ or 8 respondents) was kinship: Many payments were said to be cheaper because the transgression occurred among family members, although one person reported that a payment was expensive because it was between in-laws. One man said that he asked for a smaller payment from a clan member because the clan was becoming dispersed and he did not want to threaten its solidarity. Another man said he demanded a cheaper payment because "our children are in his uma (clan/longhouse)" (anai togamai ka umana), meaning that members of his clan had married into the offender's clan. Meanwhile, only one person used normative language to explain the magnitude of tulou, explaining that a payment was expensive because that is the rule. These converging lines of evidence suggest that tulou payments are regulated more by dyadic concerns between transgressors and victims than by third parties' concerns.

A final indication that tulou served more to restore dyadic cooperation than to avoid indirect sanctions was that individuals made payments when a victim felt transgressed upon yet no clear norm violation had occurred. In one case, a woman visited a neighboring community where she engaged in an action considered acceptable in her own community (leaving a token to announce her visit while a burial was taking place) but which was offensive in the visited community. Tulou was demanded after she returned home, which her brothers paid. Even though the woman, her brothers, and their immediate community considered the act acceptable, they paid tulou, apparently to appease the offended party. 


\section{Third parties serve as mediators}

Conflict mediation is common. Of the 217 cases for which data are available, $108(49.8 \%)$ involved mediation. The rest were determined "face-to-face" (pamatamata). Of the 108 cases involving mediation, non-governmental mediators were called in at least 81 (75\% of cases), while governmental mediators were called in at least 32 (29.6\% of cases). These percentages together exceed $100 \%$ because cases often involved multiple mediators, including, on occasion, mediators with and without government positions. Note also that these are under-estimates. In 15 mediated cases $(13.9 \%)$, disputants called mediators who held government posts at some point, although we could not determine whether they held positions at the times of the disputes.

Mediation occurs more often when cooperation is threatened. We used Bayesian logistic regression to model the probability of mediation as a function of both transgression severity and whether a transgression was within- or between-clan (model 3; see Methods). Mediation appears more likely as the severity of a transgression increases (log odds: mean $=1.11 ; 100 \%$ of posterior distribution $>0$ ). There appears to be a similar effect on mediation, although with greater uncertainty, when conflicts occur between rather than within clans (log odds ratio: mean $=-0.455 ; 86.8 \%$ of posterior distribution <0). Posterior distributions appear in Extended Data Figure 1.

We used a Bayesian negative binomial regression to investigate which demographic variables predict being called as a mediator (model 4; see Methods). Because no women or children were called as mediators, we restricted the analysis to adult men, separating men into three locally salient age classes: (1) young adults (without married children); (2) junior elders (have married children); and (3) sikebbukat, or senior elders. We found that, compared to young adults, senior elders were called more often to mediate (posterior mean $=1.4,99.3 \%$ of posterior distribution $>0$ ); the results suggest a similar effect, although with greater uncertainty, for junior elders (posterior mean $=0.641,88.9 \%$ of posterior distribution $>0$ ). Consistent with shamans serving judicial roles across cultures ${ }^{54,55}$, we found that shamans were called to mediate more often than non-shamans, accounting for age class (posterior mean $=0.837,95.8 \%$ of posterior distribution $>0$ ). Posterior distributions appear in Figure 4.

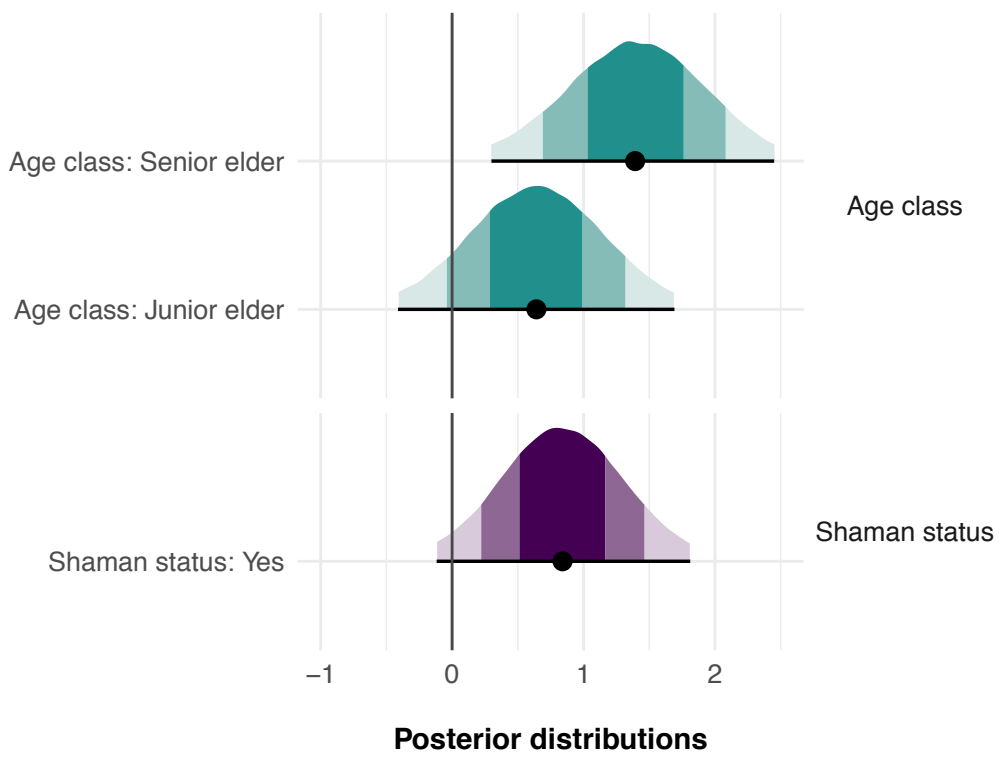

Figure 4: Predictors of being called to mediate. The figure shows the estimated coefficients ( $x$-axis) for predicting how many times an adult man is called to mediate ( $n=54$ adult men). 'Age class' refers to whether a man is a young adult (no unmarried children; reference level), junior elder (married children), or senior elder (sikebbukat). 'Shaman status' is a binary variable capturing whether or not an individual is a shaman. Points and error bars are posterior means with $95 \%$ credible intervals. The shaded areas and distributions respectively represent $50 \%, 80 \%$, and $95 \%$ of the posterior distributions. 
Mediators were often third parties. Of 72 non-governmental mediators for which there is relevant data, $55(76.4 \%)$ did not share clan membership with either disputant. In total, of the 71 cases mediated by non-governmental mediators and for which relevant data are available, 53 $(74.6 \%)$ were mediated by individuals who did not share clan membership with either disputant.

Although raw frequencies indicate that third parties mediators are often called, they do not indicate whether disputants seek out third parties more than would be expected by chance. We thus simulated data to determine the expected frequency of third-party mediation if disputants randomly select mediators. Given that we have conducted an exhaustive survey of the residents of Community A, we used the community's demographics to create the simulations. We created 1000 simulated samples, each containing 23 cases, or the number of cases collected for which both disputants lived in Community $A$ and a non-governmental mediator was called. In our simulations, random pairs of households came into conflict and called one or more senior elders to intervene; the number of mediators was randomly drawn from observed cases. We calculated the frequency of "unrelated" mediators-i.e., mediators who did not share clan membership with either disputant-in each simulated sample.

Figure 5 shows the simulated distributions of frequencies of "unrelated" (i.e., third-party) mediators in cases both between clans (Figure 5A) and within clans (Figure 5B). We found that, for between-clan transgressions, people appear not to consider whether a mediator is a third party. Of mediators called for between-clan cases in Community A, $70.6 \%$ did not share clan membership with either disputant; $43.4 \%$ of simulated samples produced lower frequencies. For between-clan transgressions, in other words, disputants appear not to consider clan membership, neither preferring nor avoiding third-party mediators.

A

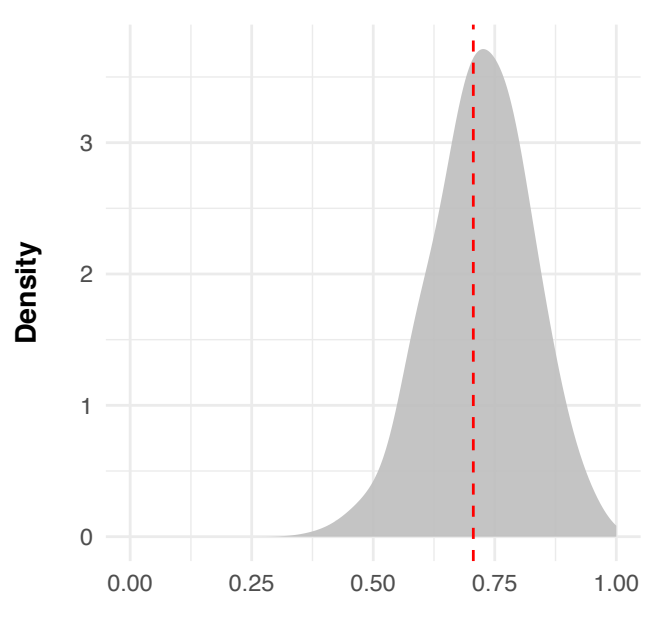

Proportion of 'unrelated' mediators
B Within-clan cases

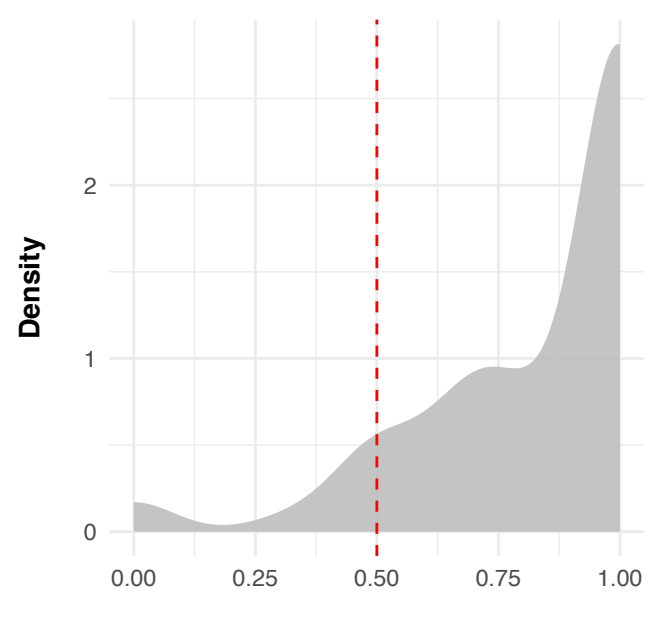

Proportion of 'unrelated' mediators

Figure 5: Simulated rates of third-party mediation. Both panels show the distributions of frequencies of mediators who do not share clan membership with either disputant ('unrelated' mediators), assuming disputants randomly select mediators from the pool of elders, according to simulations. The panels show the expected and observed frequencies for between-clan cases $(A)$ and for within-clan cases $(B)$. The $\mathrm{x}$-axis denotes the proportion of unrelated mediators; the $y$-axis represents the number of simulated populations exhibiting a given proportion. Red dotted lines denote observed frequencies in the primary study community ('Community A').

The results trend differently when transgressions occur among members of the same clan. Of mediators called in Community A for within-clan disputes, $50 \%$ did not share clan membership with either disputant. Only $15.3 \%$ of simulated samples produced lower frequencies. If we restrict the comparison to simulated samples with the same number of mediators as observed in Community A, $10.9 \%$ of simulated samples produced lower frequencies. Although $50 \%$ of within-clan conflicts still 
involve outside mediation, same-clan disputants may call fellow clan members to mediate more often than would be expected by chance.

Finally, we compared the roles of government officials and non-governmental mediators (model 5; Methods). Disputants call governmental and non-governmental mediators when cases are more severe, although there is no clear difference between the severity of cases involving the different categories of mediator (governmental mediators: mean coefficient $=0.937 ; 95 \%$ Bayesian credible interval $=[0.544,1.32]$; non-governmental mediators: mean coefficient $=1.17 ; 95 \%$ Bayesian credible interval $=[0.881,1.46]$; see Extended Data Figure 2).

\section{Discussion}

We found no evidence that third parties directly punished transgressors, such as by demanding that transgressors pay tulou or seizing resources from them after they refused to pay. Several researchers have argued that, even if third parties do not directly punish violations, they engage in second-order or indirect enforcement, such as by avoiding non-punishers as social partners ${ }^{10,14,18,51}$. We did not find evidence of such higher-order or indirect sanctions. Although we acknowledge that they are harder to document using our case-based method, several lines of evidence suggested that dyadic concerns regulated tulou more than third-parties' concerns. We found that $17.1 \%$ of cases were followed by no tulou payments and that, as predicted by dyadic models, payments were more likely when dyadic cooperation was under greater threat. Moreover, in anecdotal reports, participants often explained the magnitude of tulou payments by pointing to dyadic concerns—specifically, to kinship_rather than to third parties' concerns. These findings do not exclude the possibility of indirect third-party enforcement, but they suggest that, at the least, it is ineffective at regulating penalties compared to dyadic concerns.

Our results contrast with observations by Mathew and Boyd, who argued that, among the Turkana (Kenyan pastoralists), third-party punishment was critical for sustaining cooperation ${ }^{11}$. These differences may reflect contrasting domains of cooperation. Mathew and Boyd studied contributions to a public good (group defense), whereas our sample mostly, if not exclusively, comprised private infractions such as theft and adultery. Although the Mentawai engage in large-scale cooperation, such as when groups of 50 or more men work together to move houses or drag fleets of canoes, the benefits accrue to only a few individuals who are responsible for compensating participants. Were the Mentawai to engage in cooperative endeavors that involve many participants and produce shared benefits, such as large-scale warfare, we might expect different responses to infractions. Nevertheless, the difference between public and private concerns can be blurry. Adultery or theft tend to be private concerns, yet how they resolve impacts social harmony, a public good. Naturalistic studies in diverse societies will help resolve when and why third parties punish.

While there was little evidence of third-party enforcement, we found that third parties were often called to mediate disputes. Even in within-clan disputes, for which disputants seemed to prefer same-clan mediators, half of all mediators came from outside of the clan. Nevertheless, we did not find evidence that disputants in different clans actively seek out third-party mediators. Rather, they seem to call shamans and elders, many of whom are incidentally third parties.

Our study has several limitations. For one, our ability to capture indirect sanctions was limited. We could not, for instance, measure the reputational effects when victims failed to enforce tulou payments or when transgressors failed to pay. Although we found evidence that dyadic concerns regulate tulou payments, these findings do not exclude the possibility that indirect sanctions also contribute. Moreover, despite covering hundreds of cases, we could not study all possible cases and responses to wrongdoing in Mentawai. Our sample did not include any cases of coordinated executions of murderers or purported sorcerers, although a participant described such an incident occurring elsewhere in southern Siberut. Similarly, our sample did not include instances in which Mentawai people were imprisoned or aggrieved parties violently attacked transgressors, yet a case exhibiting both features occurred following data collection. 
As with any ethnographic project, our study tells us little about the frequencies of third-party punishment and mediation more broadly. Nevertheless, our findings have important implications for understanding justice and institutionalized sanctions. Researchers have argued that institutionalized sanctions develop to enforce cooperative norms ${ }^{11,56}$, yet our findings suggest that tulou penalties primarily serve a different function: restoring dyadic cooperation. Following a transgression, victims apparently are less willing to cooperate with offenders until they pay costs, a desire which may reflect retributive sentiments (serving to deter dyadic aggression ${ }^{53}$ ) or fairness preferences. Victims can appease this desire by attacking the aggressor in violent retribution. But aggressors might interpret such violence as excessive, risking dangerous cycles of feuding. As long as victims and aggressors wish to restore cooperation, they should find ways of satisfying retribution while sidestepping cycles of violence. Tulou appears to fulfill this function, imposing regulated costs to restore cooperation.

Some of our results supporting the cooperation-restoration hypothesis are consistent with other interpretations. Namely, the finding that tulou payments are less likely following conflicts among clan members may simply be due to family members being less willing to impose costs on each other, such as because of kin selection or fitness interdependence ${ }^{27}$. Nevertheless, other observations of tulou corroborate the cooperation-restoration hypothesis. As Box 2 illustrates, negotiations over tulou payments are constantly tied to dyadic cooperation. Aman Raman's son agreed to a cheaper payment, because, in his words, he wanted to maintain good relationships with Opa Kerei and his clan. A theme throughout the discussion was to avoid a feud, and Opa Kerei's cousin concluded by clarifying that, for him, there was no feud. The cooperation-restoration function is further evidenced when offenders do not pay tulou. Tulius documented cases in Mentawai history when a conflict occurred, no tulou was paid, and cooperation unraveled, resulting in clan fission or two clans growing increasingly distant ${ }^{35}$. Of course, patulougat may have developed to restore dyadic cooperation while also incidentally enforcing norms. Even then, however, social order seems to result less from the threat of third-party or collective enforcement, and more from a network of parties (kin groups, families, individuals) dyadically bargaining over cooperative standards. Rather than deciding whether "to punish or repair" after a transgression ${ }^{57}$, the Mentawai use a combination of penalties and compensation to repair cooperative relationships.

A second implication of our study concerns leadership in small-scale societies. Comparative analyses suggest that conflict resolution is a major component of leadership in politically decentralized societies ${ }^{30,32}$, and our findings that disputants preferentially call shamans and senior elders to mediate disputes echoes this pattern. Our results also shed light on the importance of leadership in within- compared to between-group contexts. We found that disputants in the same clan preferred within-group mediators, consistent with ethnographic descriptions of conflict resolution ${ }^{31}$. Yet we also found that disputants called third-party shamans and elders, suggesting a pathway by which leaders may accrue reputational capital beyond their kin group ${ }^{58}$. Finally, our finding that disputants preferentially called shamans adds to a literature demonstrating supernatural expertise as a contributor to social influence and one's perceived ability to provide community benefits $^{30,54,55,59,60}$.

A final implication of our study concerns the relationship of governmental intervention to local leadership institutions. Anthropologists have suggested that the apparent egalitarianism of some small-scale societies may in fact reflect powerful states or chiefdoms displacing local leaders $^{61,62}$. Among the Chabu forager-horticulturalists of Southwest Ethiopia-a population that has recently began to integrate with state-based institutions-Garfield and Hagen documented a shift in community influence from traditional elders towards younger, elected leaders ${ }^{63}$. Consistent with these views, we found that government mediation seems to substitute for local mediation. Although disputants sought out mediation when transgressions were of greater severity, there was no clear difference in the severity of transgressions for which people sought out government officials and those for which they called non-governmental mediators. Future studies can reveal whether government intervention is driving the dissolution of local leadership institutions among the Mentawai. 
As with Wiessner's study of norm enforcement among the Enga (Papua New Guinea) ${ }^{34}$, we find that the focus on third-party punishment leads to a misleading and impoverished view of how humans regulate cooperation. Rather than third parties punishing norm violators, offenders and victims engage in rhetorical back-and-forths. They discuss whether a transgression occurred, its severity, to what extent the offender benefited, whether the infraction was intentional, and whether the offender deliberately hid the information afterwards. Over hours and sometimes days, and with the help of trusted mediators, the two parties determine a transfer of resources that imposes costs on the offender and compensates the victim. Some victims refrain from demanding payments; some transgressors refuse to pay them. These decisions, in turn, affect their relationships. In Mentawai, cooperation emerges as individuals negotiate over how to best treat each other.

\section{Methods}

This research was approved by the Harvard University Committee on the Use of Human Subjects and the Ministry of Research, Technology, and Higher Education of the Republic of Indonesia.

\section{Ethnographic fieldwork}

Data for this project were collected as a part of long-term ethnographic fieldwork conducted by M.S. in southern Siberut. To date, M.S. has conducted 12 months of fieldwork in Siberut and has working proficiency in the Rereiket dialect of Mentawai. The quantitative data collection and participantobservation relevant for this study occurred particularly during a duration of 7.5 months in 2017 during which M.S. lived, to the best of his ability, immersed in Community A. He visited Community A first in 2014 and stayed with a family during the summer of 2015. In April 2017, M.S. consulted with the community to construct a small house on a local clan's land. The house was built and designed by members of community $A$ and close to other houses in the community. One to two Mentawai research assistants lived with him for the duration of period. Giving his clear interests in tulou, M.S. was invited to observe and record tulou discussions, during which he was expected to provide tea, coffee, sugar, and biscuits.

\section{Data collection}

M.S. conducted 199 interviews with 95 participants (65 males, 30 females), including with a member of each household in the primary study community ("Community A"). Interviews were conducted in May, June, November, and December of 2017 and in the Rereiket dialect of Mentawai. A research assistant proficient in English, Indonesian, and the Rereiket dialect accompanied M.S. for most interviews and, when necessary, clarified participants' responses either during the interview or afterwards. Efforts were made to interview participants privately and out of earshot, usually either in M.S's house or the participant's house. All participants were paid 15,000 IDR (1.13 USD on July 1, 2017) as compensation for their time.

Given that many participants lack functional literacy, verbal rather than written consent was sought. All participants were assured that identifying details would not be shared and were informed of the study's aims of characterizing Mentawai law and sharing the findings with people outside of Mentawai. All participants provided verbal informed consent before participating in the study.

Participants were asked to share details about any tulou payments they were aware of, focusing on cases in which they were involved. They were also asked about cases in which an individual transgressed but no tulou was paid. For each case, they were asked to specify the identities of the disputants, the transgression, the identity of the patalaga (mediator), an estimate of when the case happened, its location, whether tulou was paid, and, if it was paid, its original composition. If a payment appeared especially cheap or expensive, participants were asked why. Details about cases were corroborated in one of four ways: (1) Multiple participants spontaneously described the same case; (2) M.S. attended discussions of tulou payments or was otherwise aware of a payment; (3) participants were explicitly asked to corroborate cases that others mentioned; or (4) participants were re-interviewed to corroborate previous reports. 
Details about 444 cases were collected. Because much of our data comprise retrospective reports, we used a set of exclusion criteria to restrict the sample to a more reliable set of cases. We excluded cases in any of the following categories: (1) the case referred to a general expectation rather than to an actual case; (2) key details of the case remain unresolved, confusing, or missing; (3) the research assistant or other people interviewed expressed skepticism about the reliability of the case; (4) the case resulted in an outcome other than a tulou payment or lack of payment (e.g., a transgression sparked a counter-attack ultimately concluding in an exchange of resources); and (5) all corroborations failed.

Tulou payments were composed almost exclusively of local resources such as pigs, chickens, iron woks, durian trees, and sago gardens. To convert these into a common currency, M.S. arranged focus groups during and at the end of data collection (June and December 2017) and determined the value of all resources in Indonesian rupiah. Supplementary Table 1 lists items with their corresponding estimates in Indonesian rupiah.

Demographic data were collected during a survey of Community A in April 2017 and updated throughout the year. The analyses reported here draw on five demographic variables: sex, marital status, patrilineal clan, age class, and household head status.

\section{Analyses}

All analyses were conducted in $\mathrm{R}$ version 4.0.5. All regressions were conducted in a Bayesian framework using the rstanarm package ${ }^{58}$ version 2.21.1 (with four Markov chains and 20,000 iterations following a warmup of 20,000 iterations). For all model covariates we used regularizing priors, set at $\sim N(0,1)$, which function to impose greater conservatism on parameter estimates and reduce Type-S error rates relative to frequentist approaches or flat priors ${ }^{64,65}$. Priors for intercepts used Student's $t$ distributions, set at $\sim t_{7}(0,2.5)$. We elaborate on the specifics of each model below (see Supplementary Tables 3, 4, 6, 8, and 10 for model results and Supplementary Tables 5, 7, and 9 for results of model comparisons).

Models 1 and 2: We used logistic regression to model the effect of a payment occurring on both the severity of the transgression and whether a transgression was within-clan or between-clan. Severity was calculated by averaging, within a given category of transgression (e.g., "sorcery"), all estimated tulou values for all transgressions followed by a payment. We used Bayesian leave-oneout cross-validation to evaluate model performance, comparing a full model (two predictors) to an intercept-only model and single predictor (shared clan status) model. The full model outperformed both the intercept-only and single predictor model. In the text, we report the results of the singlepredictor model (model 1) and the full model (model 2); we display posterior distributions of model 2 in Figure 3.

Model 3: Similar to models 1 and 2, we used logistic regression to model the effect of mediation occurring on both the severity of the transgression and whether a transgression was within-clan or between-clan. We used Bayesian leave-one-out cross-validation to evaluate model performance, comparing a full model (two predictors) to an intercept-only model. We found that the full model outperformed the intercept-only model. We report the results of the full model in the text and display posterior distributions in Extended Data Figure 1.

Model 4: We modeled the number of times an individual was called to mediate, a count variable, as a function of shaman status and age class. Age class was originally coded in five bins: non-adult (0); unmarried adult (1); married adult without married children (2); married adult with married children, or junior elder (3); and sikebbukat, or senior elder (4). For the analyses reported here, we combined age classes 1 and 2 because very few individuals fell into age class 1 . For model 4 , we also excluded all females and non-adults because none were called to mediate.

Because our data were overdispersed with excessive zeroes, we compared simulated data sets under Poisson and negative binomial distributions to the observed values (using the pp_check function in rstanarm). We found that a negative binomial distribution better estimated the frequency of zeroes in our data (Supplementary Figure 2). We used Bayesian leave-one-out cross-validation to evaluate model performance, comparing a full model (two predictors) to single-predictor models and 
an intercept-only model. We found that the full model performed best. We report the results of the negative binomial regression in the text and display posterior distributions in Figure 4.

Model 5: To compare the severity of transgressions mediated by local mediators to the severity of transgressions mediated by government officials, we used Bayesian linear regression to model severity as a function of two dummy variables: (1) whether a case was mediated by a local mediator, and (2) whether a case was mediated by a government official. We could not use a binary variable for the category of mediation (e.g., 0 = local mediator; 1 = government official) because some cases were mediated by individuals of both categories. We display the posterior distributions in Extended Data Figure 2.

Data availability: All cleaned, anonymized data are available at the OSF project page at https://osf.io/r5jv6/.

Code availability: All code used in analyses is available at the OSF project page at https://osf.io/r5jv6/.

Acknowledgements: L. Fitouchi, L. Glowacki, J. Henrich, H. Larreguy, S. Mathew, C. Molho, C. von Rueden, and members of IAST's Social Evolution Team shared valuable comments on earlier versions of this manuscript. M. Delfi, B. Sakaliou, and G. Sakaliou assisted with fieldwork. R. Henry and J. Tulius assisted with clarifying Mentawai terminology. Data collection by M.S. was funded by a National Science Graduate Research Fellowship, a Sheldon Traveling Fellowship from the Harvard Committee on General Scholarships, and a grant from the Mind, Brain, and Behavior Initiative at Harvard University. Both authors acknowledge IAST funding from ANR under grant ANR-17-EURE0010 (Investissements d'Avenir program).

Author contributions: M.S. collected data as part of ongoing field research. M.S. and Z.G. conceived the study, designed and conducted analyses, and wrote the manuscript.

Competing interests: The authors declare no competing interests. 


\section{References}

1. Durkheim, E. The division of labor in society. (1984). doi:10.5840/zfs 19343310.

2. Boyd, R., Gintis, H., Bowles, S. \& Richerson, P. J. The evolution of altruistic punishment. Proc. Natl. Acad. Sci. U. S. A. 100, 3531-3535 (2003).

3. Boyd, R., Gintis, H. \& Bowles, S. Coordinated punishment of defectors sustains cooperation and can proliferate when rare. Science (80-. ). 328, 617-20 (2010).

4. Boyd, R. \& Richerson, P. J. Punishment allows the evolution of cooperation (or anything else) in sizable groups. Ethol. Sociobiol. 13, 171-195 (1992).

5. Marshall, J., Yudkin, D. A. \& Crockett, M. J. Children punish third parties to satisfy both consequentialist and retributive motives. Nat. Hum. Behav. 5, 361-368 (2021).

6. Hamlin, J. K., Wynn, K., Bloom, P. \& Mahajan, N. How infants and toddlers react to antisocial others. Proc. Natl. Acad. Sci. U. S. A. 108, 19931-19936 (2011).

7. Heyman, G. D., Chiu Loke, I. \& Lee, K. Children spontaneously police adults' transgressions. J. Exp. Child Psychol. 150, 155-164 (2016).

8. House, B. R. et al. Social norms and cultural diversity in the development of third-party punishment. Proc. R. Soc. B Biol. Sci. 287, (2020).

9. Balafoutas, L., Nikiforakis, N. \& Rockenbach, B. Direct and indirect punishment among strangers in the field. Proc. Natl. Acad. Sci. U. S. A. 111, 15924-15927 (2014).

10. Mathew, S. How the second-order free rider problem is solved in a small-scale society. Am. Econ. Rev. 107, 578-581 (2017).

11. Mathew, S. \& Boyd, R. Punishment sustains large-scale cooperation in prestate warfare. Proc. Natl. Acad. Sci. U. S. A. 108, 11375-80 (2011).

12. Leeson, P. T. An-arrgh-chy: the law and economics of pirate organization. J. Polit. Econ. 115, 1049-1094 (2007).

13. McDowell, A. G. From Commons to Claims: Property Rights in the California Gold Rush. Yale J. Law Humanit. 14, 1-72 (2002).

14. Hadfield, G. K. \& Weingast, B. R. Law without the state: legal attributes and the coordination of decentralized collective punishment. J. Law Court. 1, 1-34 (2013).

15. Boehm, C. Moral origins: The evolution of virtue, altruism, and shame. (Basic Books, 2012).

16. Wrangham, R. W. The goodness paradox: The strange relationship between peace and violence in human evolution. (Vintage, 2019).

17. Wrangham, R. W. Targeted conspiratorial killing, human self-domestication and the evolution of groupishness. Evol. Hum. Sci. 3, e26 (2021).

18. Boyd, R. A different kind of animal: How culture transformed our species. (Princeton University Press, 2018).

19. Henrich, J. et al. Markets, religion, community size, and the evolution of fairness and punishment. Science (80-. ). 327, 1480-1484 (2010).

20. Baumard, N. Has punishment played a role in the evolution of cooperation? A critical review. Mind Soc. 1-22 (2010) doi:10.1007/s11299-010-0079-9.

21. Black, D. On the origin of morality. J. Conscious. Stud. 7, 107-119 (2000).

22. Marlowe, F. W. et al. More 'altruistic' punishment in larger societies. Proc. Biol. Sci. 275, 587-90 (2008).

23. Berndt, R. M. \& Berndt, C. H. The world of the first Australians: Aboriginal traditional life: Past and present. (Aboriginal Studies Press, 1988).

24. Berndt, R. M. Law and order in aboriginal Australia. in Aboriginal man in Australia: Essays in honour of Emeritus Professor A. P. Elkin (eds. Berndt, R. M. \& Berndt, C. H.) 167-206 (Angus and Robertson, 1965).

25. Raihani, N. J. \& Bshary, R. Punishment: One tool, many uses. Evol. Hum. Sci. 1, 1-26 (2019).

26. Hoebel, E. A. The law of primitive man: A study in comparative legal dynamics. (Harvard University Press, 1954).

27. Henrich, J. \& Muthukrishna, M. The origins and psychology of Human Cooperation. Annu. Rev. Psychol. 72, 207-240 (2021).

28. Boyd, R. \& Mathew, S. Arbitration supports reciprocity when there are frequent perception errors. Nat. Hum. Behav. 5, 596-603 (2021).

29. Smith, J. E. et al. Leadership in mammalian societies: emergence, distribution, power, and payoff. 
Trends Ecol. Evol. (2015) doi:10.1016/j.tree.2015.09.013.

30. Garfield, Z. H., Syme, K. L. \& Hagen, E. H. Universal and variable leadership dimensions across human societies. Evol. Hum. Behav. 41, 397-414 (2020).

31. Garfield, Z. H. Correlates of conflict resolution across cultures. Evol. Hum. Sci. 3, e45 (2021).

32. Glowacki, L. \& von Rueden, C. Leadership solves collective action problems in small-scale societies. Philos. Trans. R. Soc. B 370, 20150010 (2015).

33. Wiessner, P. Norm enforcement among the Ju/'hoansi Bushmen. Hum. Nat. 16, 115-145 (2005).

34. Wiessner, P. The role of third parties in norm enforcement in customary courts among the Enga of Papua. Proc. Natl. Acad. Sci. 117, 32320-32328 (2020).

35. Tulius, J. Family stories: oral tradition, memories of the past, and contemporary conflicts over land in Mentawai - Indonesia. (Leiden University, 2012).

36. Indigenous Education Foundation. 2011-2012 community research report. (2012).

37. Schefold, R. Lia: Das grosse Ritual auf den Mentawai-Inseln (Indonesien). (Dietrich Reimer Verlag, 1988).

38. Delfi, M. Local belief system, tatouage, tradition and adaptation in Mentawai. in Proceedings of the 3rd International Indonesian Forum for Asian Studies 900-911 (2017).

39. Hammons, C. S. Sakaliou: Reciprocity, mimesis, and the cultural economy of tradition in Siberut, Mentawai Islands, Indonesia. (University of Southern California, 2010).

40. Singh, M. \& Henrich, J. Why do religious leaders observe costly prohibitions? Examining taboos on Mentawai shamans. Evol. Hum. Sci. 2, e32 (2020).

41. Singh, M., Kaptchuk, T. J. \& Henrich, J. Small gods, rituals, and cooperation: The Mentawai water spirit Sikameinan. Evol. Hum. Behav. 42, 61-72 (2021).

42. Schefold, R. Ambivalent blessings: Head-hunting on Siberut (Mentawai) in a comparative Southeast Asian perspective. Anthropos 102, 479-494 (2007).

43. Loeb, E. M. Mentawei social organization. Am. Anthropol. 3, 408-433 (1928).

44. Tulius, J. Contemporary contentions of ancestral land rights among indigenous kin-groups in the Mentawai Islands of Indonesia. in Heritage and rights of indigenous peoples (Patrimonio y derechos de los pueblos indigenas) (eds. Castillo, M. M. \& Strecker, A.) 109-136 (Leiden University Press, 2017).

45. Delfi, M. Islam and Arat Sabulungan in Mentawai. Al-Jami'ah J. Islam. Stud. 51, (2013).

46. Schefold, R. The culinary code in the puliaijat ritual of the Mentawaians. Bijdr. tot Taal-, Land-en Volkenkd. 138, 64-97 (1982).

47. Caissutti, T. La cultura Mentawaiana. (Asian Study Centre, 2015).

48. Darmanto, D. Good to produce, good to share: Food, hunger, and social values in a contemporary Mentawaian community, Indonesia. (Leiden University, 2020).

49. Persoon, G. A. Views of participating outsiders: Two civil servants leaving the island of Siberut (Mentawai Archipelago, Indonesia). in The Leiden tradition in structural anthropology: Essays in honor of P. E. de Josselin de Jong (eds. de Ridder, R. \& Karremans, J. A. J.) 140-160 (Brill, 1987).

50. Persoon, G. A. Vluchten of veranderen: Processen van verandering en ontwikkeling bij tribale groepen in Indonesië. (Leiden University, 1994).

51. Panchanathan, K. \& Boyd, R. Indirect reciprocity can stabilize cooperation without the secondorder free rider problem. Nature 432, 499-502 (2004).

52. Delton, A. W. \& Krasnow, M. M. The psychology of deterrence explains why group membership matters for third-party punishment. Evol. Hum. Behav. 38, 734-743 (2017).

53. McCullough, M. E., Kurzban, R. \& Tabak, B. A. Cognitive systems for revenge and forgiveness. Behav. Brain Sci. 1-58 (2013) doi:10.1017/S0140525X11002160.

54. Singh, M. The cultural evolution of shamanism. Behav. Brain Sci. 41, e66 (2018).

55. Winkelman, M. J. Shamans and other 'magico-religious' healers: A cross-cultural study of their origins, nature, and social transformations. Ethos 18, 308-352 (1990).

56. Fehr, E. \& Fischbacher, U. Third-party punishment and social norms. Evol. Hum. Behav. 25, 6387 (2004).

57. Petersen, M. B., Sell, A., Tooby, J. \& Cosmides, L. To punish or repair? Evolutionary psychology and lay intuitions about modern criminal justice. Evol. Hum. Behav. 33, 682-695 (2012).

58. Garfield, Z. H. et al. The content and structure of reputation domains across human societies: a view from the evolutionary social sciences. Philos. Trans. R. Soc. B Biol. Sci. 376, (2021). 
59. Lightner, A. D., Heckelsmiller, C. \& Hagen, E. H. Ethnoscientific expertise and knowledge specialisation in 55 traditional cultures. Evol. Hum. Sci. (2021) doi:10.1017/ehs.2021.31.

60. Sahlins, M. D. Poor man, rich man, big-man, chief: Political types in Melanesia and Polynesia. Comp. Stud. Soc. Hist. 5, 285-303 (1963).

61. Singh, M. \& Glowacki, L. Human social organization during the Late Pleistocene: Beyond the nomadic-egalitarian model. EcoEvoRxiv Prepr. (2021).

62. Wiessner, P. Pathways of the past: !Kung San hxaro exchange and history. in Überlebensstrategien in Afrika (eds. Bollig, M. \& Klees, F.) 101-124 (Heinrich-Barth Institut, 1994).

63. Garfield, Z. H. \& Hagen, E. H. Investigating evolutionary models of leadership among recently settled Ethiopian hunter-gatherers. Leadersh. Q. 31, 101290 (2020).

64. Ghosh, J., Li, Y. \& Mitra, R. On the use of cauchy prior distributions. Bayesian Anal. 13, 359-383 (2018).

65. Gelman, A. \& Tuerlinckx, F. Type S error rates classical and Bayesian single and multiple comparison procedures. Comput. Stat. 15, 373-390 (2000). 


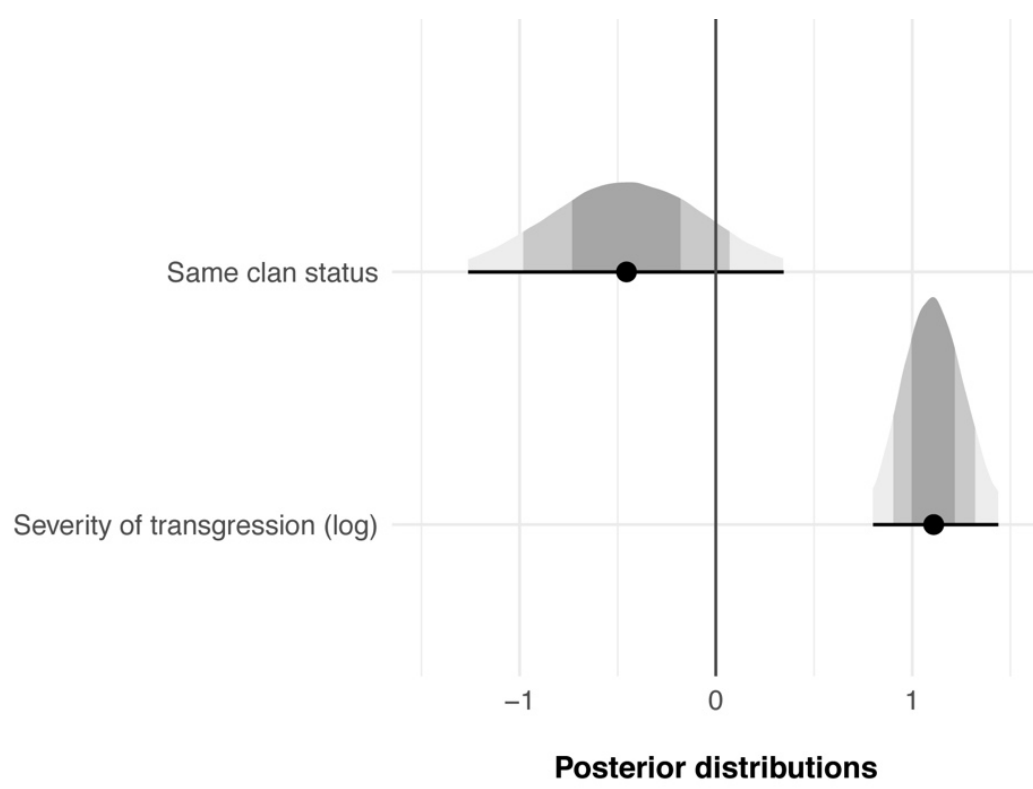

Extended Data Figure 1: Predictors of a case being mediated. The figure shows the estimated log odds ( $x$-axis) for predicting whether a mediator was called (model 3$)$ ( $n=199$ cases). 'Same clan status' is a binary variable capturing whether disputants are in the same clan (1) or different clans (0). Points and error bars are posterior means with $95 \%$ credible intervals. The shaded areas and distributions respectively represent $50 \%, 80 \%$, and $95 \%$ of the posterior distributions. 


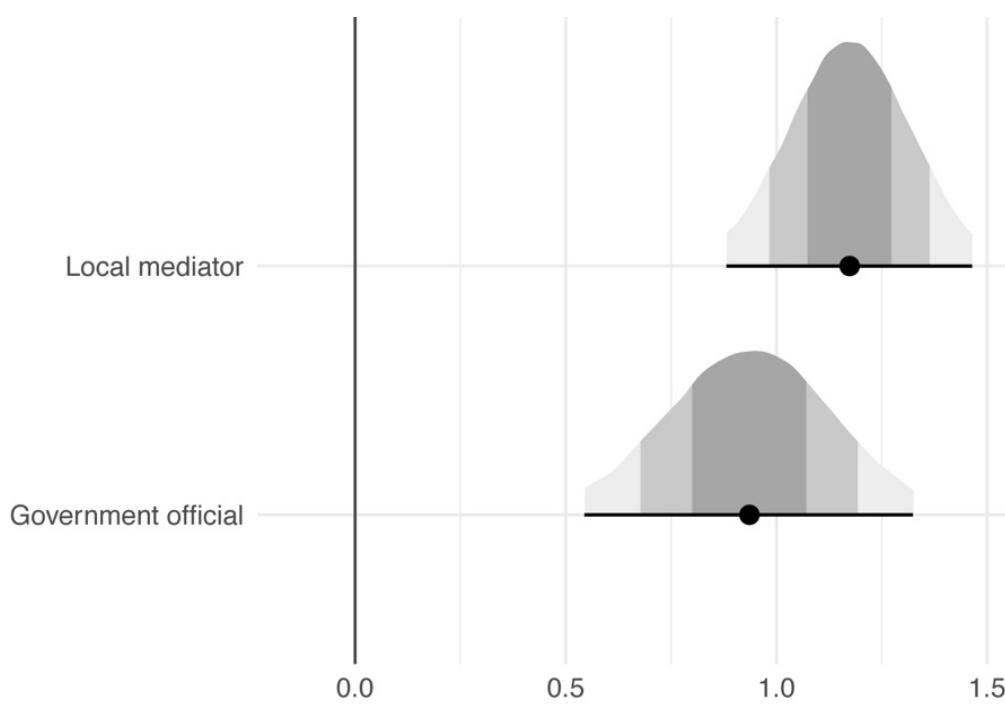

Posterior distributions

Extended Data Figure 2: Comparing governmental and non-governmental mediation. The figure shows the estimated severities of transgressions ( $\mathrm{x}$-axis) for which local mediators were called and for which governmental officials were called to mediate ( $\mathrm{n}=208$ cases). Points and error bars are posterior means with $95 \%$ credible intervals. The shaded areas and distributions respectively represent $50 \%, 80 \%$, and $95 \%$ of the posterior distributions. 